\title{
Impact Assessment of Women Farmer Activity on Poverty Reduction and Food Security: A Case of Kindia Region/Guinea
}

\author{
Moussa Camara (Corresponding author), Yali Wen \& Hongmei Wu \\ School of Economics and Management \\ Beijing Forestry University, Beijing, China \\ E-mail: panini80@yahoo.fr \\ Mory Diakite \\ China Agriculture University, Beijing, China \\ Kampungu K Gerson \& Haichang Wang \\ School of Economics and Management \\ Beijing Forestry University, Beijing, China
}

Received: January 27, 2011 Accepted: February 10, $2011 \quad$ Published: December 1, 2011

doi:10.5539/jas.v3n4p141

URL: http://dx.doi.org/10.5539/jas.v3n4p141

\begin{abstract}
In Kindia, access to food is dependent on the activity of rural women. Women farmers produce the majority of food and are responsible for ensuring that their families' basic needs are met. Today, the developing countries are faced with huge problems among which that of food insecurity remain the central point. This food insecurity manifests itself in the very acute poverty covering all aspects of the lives of the rural people. The lack of employment, low family income, inaccessibility to individuals with basic social services (drinking water, health, education, etc...) cause very critical situations. It is very clear to recognize that the people most vulnerable are those living in rural areas, most specifically women and children. They are, at the time, a particularly vulnerable group and an essential player that is contributing to the achievement of household food security in Kindia. Despite the critical role they play in food production and poverty reduction, they have ownership of only $1 \%$ of the land. This article focuses on the activity of women farmer and their contribution to food security and poverty reduction in Kindia region of Guinea.
\end{abstract}

Keywords: Agriculture, Crops, Food security, Women farmer, Poverty reduction

\section{Introduction}

A united Nation's estimate puts women's domestic food production at $80 \%$ in Africa, $60 \%$ in Asia and the Pacific and 40\% in Latin America (FAO. 1998). People's overall access to food is very dependent on the work of rural women. Women farmers produce the majority of food and are responsible for ensuring that their families' basic needs are met. Women's access to financial services, agricultural extension, education, health care and human rights are, therefore, key to assuring food security for all (Hunger Project at www.thp.org). Food security exists when all people at all times have physical and economic access to sufficient safe and nutritious food to meet their dietary needs and food preferences for an active and healthy lifestyle (WFS, 1996). In a study on rural women in food chain activities, Obinne (1995) found that women farm managers have inadequate access to extension services. Since they (women farmers) are engaged in both on-and off-farm activities they do not have time to enjoy the extension services offered. Similarly, Protz (1997) posited that due to the multiple roles women play in the rural household (including caretakers of children and the elderly), they do not fully benefit from extension services, particularly, when the time of delivery (of extension service) conflicts with their other household responsibilities. According to FAO (1998), rural women are burdened by their domestic tasks and family obligations and controlled by social restraints such that they are constrained (time-wise) not to be away from home to attend extension training programmes. The $20^{\text {th }}$ Century food production has been of remarkable 
results for the world to meet the need of human population that doubled from 3 billion to 6 billion people during the last forty years (SNPRV 2008). Women have been making prominent and important contributions to agriculture right from creation and they actually constitute the bulk of the world's food producers. Women engage in various farming activities such as planting, weeding, hoeing, harvesting, threshing and winnowing of agricultural products as well as the processing, storage and marketing of these farm produce. Many of these women farmers in the country are also directly involved in the production of some important crops as yams, maize, cassava, groundnut, Potato, water melon, among others. Similarly a good number of women in rural areas undertake many responsibilities concerning care and management of farm animals like poultry, goats and sheep (Loagun EU, 1998). Today, the rural areas are faced with huge problems among which that of food insecurity remain the central point. This food insecurity manifests itself in the very acute poverty covering all aspects of the rural lives. The lack of employment, low family income, inaccessibility to individuals with basic social services (drinking water, health, education, etc...) cause very critical situations. It is very clear to recognize that the people most vulnerable are those living in rural areas. Generally, the potential development of existing rural sector is large and diverse (agriculture, livestock, fishing, crafts, small trade, etc...). However, this rural sector is the primary source of growth in Kindia. So, helping the rural women to develop is a critical requirement that must be achieved in the fight against poverty and to achieve sustainable economic growth (Camara Moussa et al 2010). The fight against rural poverty and household food insecurity is one of the preoccupation of women farmers as well as a central theme of development policies in Guinea. From this point of view, the populations of rural areas, which are production centres that supply the rest of the country, suffer more malnutrition and the lack of the foodstuffs. The food problem in rural environment is not only attributable to the weakness of agricultural production but also to storage and mismanagement of agricultural production, the majority of the people suffering from the food insecurity problem live in rural environment. The growth of agricultural production (increase in the outputs) can have a very positive effect on the rural economy; to increase the productivity of the small farmers is particularly considerable. Agricultural growth contributes to reduce the number of the people undernourished, if the population growth is moderate. For example in China, between 1990-92 and 2001-03, the number of undernourished people fell from 194 million to 150 million and the rate of malnutrition, from 16 to $12 \%$. That was obtained by economic growth and sound agricultural policy. At the same time, the annual growth of the population was only 1\% (FAO 2009). In Kindia, Guinea, although the women farmer are the main actors in feeding the hungry and fight against poverty and food insecurity, most of their activity is unpaid or grossly underpaid and they have no training and technology. Far too little attention is paid to alleviating women's drudgery in rural areas (Erwin Northoff 1998). The poverty in Guinea is concentrated in the rural areas where poverty indicators are twice those of the urban population. The most vulnerable, at-risk groups include resource-scarce farmers, youth, and most especially women. The situation of women in rural areas needs to be improved to ensure food security and reduce the number of undernourished people. On a global scale, women cultivate more than half of all the food that is grown "Without women the humanity would undoubtedly go hungry". In Kindia region the proportion of women working in the agricultural sector is slightly higher than men: $58.2 \%$ as against $41.8 \%$. Cash crops grown in these agricultural sectors include cotton, coffee, fruits, oil palm and sorghum, while food crops include rice, cassava, maize, millet, corn and vegetables, livestock farming among others (Keita, 2006). In some districts of the region the role of women in agriculture has become increasingly dominant as men are face with forced rural migration due to severe poverty. This new trend, called the 'feminization of agriculture', (FAO.2009..) is most accentuated in the prefectures of Dubréka, Kindia and Coyah where the male population is falling rapidly and women are now forming the majority of smallholder farmers. Women head is approximately one third of rural households today. However, these women are often denied access to credit or the benefits of membership in co-operatives and farmers associations, less than $10 \%$ of women farmers in the region of Kindia own land. Without secure land rights, women farmers find it difficult to obtain financial support from banks. "This is a serious obstacle to women farmers and their productivity since they are the ones who bear the primary responsibility for their families' health, education and nutrition. In addition to their prominence in agriculture, women bear the brunt of domestic tasks: processing food crops, picking fruits, preparing and cooking food, caring for children and their husbands, (Weisfeld-Adams, and Emma 2008). An FAO study showed that female farmers receive only five percent of all agricultural extension services worldwide and that only around 15 percent of the extension agents are women. The (RNA/SNSA 2000-2001) estimates that women produce over $50 \%$ of all food grown worldwide. In Guinea the women grow $80 \%$ of the food. In Kindia region the women work far longer hours than men. On average, their workdays may be $50 \%$ longer (SNPRV2008). Women carry out essential work such as hoeing, planting, weeding and harvesting with simple tools and little outside assistance. If women were to get the same farm inputs as average men farmers do, they would increase their yields. The contribution of women to agricultural production over the years has been acknowledged and there is a need to make available to them appropriate information to enhance their 
productivity. With the aim to make our modest contribution in the struggle that leads the Guineans, this paper is thus designed to evaluate women farmers' activity on poverty reduction in Kindia region; it focuses on food security as one of the important approaches of sustainable livelihoods, and the analysis of the role of women in farming and food production.

\subsection{Women farmers and Agricultural Cooperatives}

Strong in its natural and human resources, the administrative region of Kindia in recent years has witnessed the creation of several farmers' organizations. The honour today is that of kindiakas women through their production activity. The abundance of farmers' organizations has encouraged women farmers to formalize their organizations and to create unions to defend their interests and deal with their difficulties. In this context, in the Kindia region, there are several unions with hundreds of farmers' organizations (Union of Bangouya Women, Union of Gomba Women, Union of Kolenten Women, Union of Groups of Lower Molota, Union of Gardeners of Kindia, Union Groups Madina Oulla, Union of Samaya Farmers, Union Groups of Kindia food crops, Union of Friguiagbe Planters, Union of Producers of Benty, Union of Producers Benna, Union of Producers of Moriah ...). Also, these unions are affiliated to the Federation of Peasant Organizations of Lower Guinea (FOP / $\mathrm{BG}$ ) which happens to be the umbrella organization of farmers' organizations of this administrative region (Alpha Oumar KEBE 2007). These women farmers have set objectives of social and economic characteristics.

\section{Social objectives}

The promotion of rural producers (especially women) and strengthening their socio-economic position by:

- The representation and advocacy of members at national and regional level

- Arbitration of internal conflicts and support the functioning of groups and members of literacy

\section{Economic objectives}

- The supply of producers of agricultural inputs, improved seeds and fertilizers

- Increased yields through new agricultural techniques and food gardening

- The conversion of Shallow

- Reforestation of cleared areas heavily and mainly the heads of sources

- The protection of parcel against the animals straying

This practice allows the combining of forces for greater efficiency in accordance with the adage "unity is strength." Thus in these fields, the women sowed the crops (rice and cassava) which they sell to get money needed for the achievement of certain public infrastructure (schools, wells, improved drilling ...)_

\section{Establishment of a fund of credit tontine}

In addition, experience exchange visits were organized by farmers initiated by the Pilot Project of Support to Special Programme for Food Security-Kindia (Kindia PPA/PSSA).

A sensitization of cooperative members has been to collect the money, after the formation of the fund managers; beneficiary groups of granting credit have an interest rate of $15 \%$ for maturities of 6 months time refund. This amount helps solve one part of the financial difficulties of farmers and also helps to increase their income. The establishment of this fund Tontine /credit will allow farmers to finance themselves (Camara Moussa et al 2005).

\section{Methodology}

The region of Kindia is one of eight administrative regions of Guinea. It covers an area of $26,932 \mathrm{~km}^{2}(11 \%$ of the National area) with a population of $1,327,486$; (13\% of the Guinean population), with an average annual growth rate of $4 \%$ (2010 census) and an average density of 34.5 inhabitants per square kilometer and it's located in western Guinea, bordered in the west and north by the region of Boké, to the east by the regions of Mamou and Labé and the south by Sierra Leone and the region of Conakry. It has five prefectures and 45 sub prefectures namely Coyah Prefecture (Coyah town, Kouriah, Wonkifon and Maneah), Dubréka Prefecture (Dubréka town, Tanene, Corrérah, Ouassou, faléssadé, Bady and Tondon), Forecariah Prefecture (Forecariah town, Allasoyah, kallia, Benty, Farmoriah, Sikhourou, Moussayah, Kakossa, Mafèrinya and Kaback), Kindia Prefecture (Kindia town, Bangouyah, Souguéta, Samaya, Danmakania, Kolenté, Friguiagbe, Molota, Madina oula and Manbia) and Télimélé Prefecture (Télimélé town, Koba, Missira, Konsotami, Santou, Bourouwal, Sarékaly, Daramagniki, Gougoudie, Sogolon, Kollet, Thionthian, Sinta and Tarihoye). The town of Kindia is also referred to as the government seat. The climate is generally tropical, semi humid called "sudano-guinean". It is characterized by two distinct seasons with a rainy season of 6 months starting from May to October and a dry season from November to May. The average rainfall varies from 1900 to $3600 \mathrm{~mm}$ per annum. The farmer population 
accounts for $80 \%$ of the total population of the region and takes $79 \%$ of its income from agricultural activities. The major economic activities of the people include farming, trading and handicraft. The major crops are rice, cassava, pineapple, water melon, sweet potato, plantain, oil palm, fonio, citrus, mango, banana, palm, and kola nut, avocado, vegetable, maize, coconut, orange, and other fruits etc. More so, it consists of marshy plains with a few mountains: Gangan (1116 m), Benna (1124 m), Kakoulima (1,011 m). (see Map )

To realize this general impact assessment, the following methodology adopted was consultation of human resources in rural areas with questionnaire on basic indicators of well-being to have better evaluation of women farmer activity and poverty incidence, reading reference books and research papers to have better understanding women actions and movements on food security and poverty reduction in Kindia. A Group of researchers designed a five page questionnaire based on previous studies conducted in Guinea. The choice of the sample was Kindia administrative regions. The data collected concerns agricultural production, input/output market information, and household food security. Out of the 45 sub-prefectures currently participating in the agriculture activities 34 of them were randomly selected and they are directly involved in the subsistence farming, namely: Wonkifon, Maneah, Kouriah, Coyah town, Benty, Farmoriah, Allasoyah, Moussayah, kallia, Kakossa, Mafèrinya, Sogolon, Kollet, Koba, Missira, Konsotami, Sarékaly, Daramagniki, Santou, Bourouwal, Bady, Tondon, Ouassou, Tanene, Corrérah, Faléssadé, Kindia town, Danmakania, Friguiagbe, Bangouyah, Samaya, Kolenté, Molota, and Manbia. This approach involves participation, dialogue and consultation with rural cooperatives and the sample of 114 districts was randomly selected from the 34 sub-prefectures that practice subsistence farming. Similarly, the number of women carrying out livestock was listed for each village and a sample of ten women per district was randomly selected. Thus a total of 1140 women were interviewed during the investigation with $80 \%$ of the Geographic coverage. Nowadays the poverty covers all rural areas in Kindia region. Nonetheless, it should be noted that the financial and time constraints do not allow us to go into all the districts.

\section{Results}

The participation of women in agricultural activities is sufficiently explored in this report and appears in more detail in all the various themes developed. Women bear the bulk of farm activities and agricultural labour.

\subsection{Population and Agricultural exploitation}

The agricultural population of the region of Kindia is characterized by a predominance of women population. They represent approximately $15.4 \%$ of the total population and $51.6 \%$ at the regional level. At the prefectural level the percentage of women varies slightly from 50\% in Télimélé, 51\% in Dubréka, 49\% in Forecariah, 55\% in Kindia and 53\% Coyah. This predominance of women population is caused by the rural migration of men in search of wage employment in the towns and cities; hence the number of households with women head is relatively high. The proportion of the population more active (20-54 years) is higher among women than men. The educational level of rural women population is very low and represents only $5 \%$ at regional level. The proportion of women in agriculture is more important (51.6\%) than men (48.4\%). Women carry a relatively secondary activity than men. Their activities are mainly market gardening, trade, fisheries, saponification, dyeing, and extraction of salt. The proportion of manager is fairly similar between man and woman. More than half of farms managed by men aged between 5 and 9 persons and more than $40 \%$ of farms managed by women have less than 5 people of the 203 farms at the regional level visited by this research team, 91 are headed by women, which is approximately 44, $8 \%$. Although in the prefectures of Kindia, Coyah and Forecariah there is a high proportion of female household heads, but depending on the size of holdings, results show that $70 \%$ of farms managed by women have less than 5 people. The female workforce is mainly used in maintenance, harvesting and a little in the ploughing and sowing (See Graph: $1 \& 2$ ).

\subsection{Women agricultural Workforce}

According to the prefectures, Télimélé employs the highest percentage of women labor followed by Dubréka, Kindia, Forecariah and Coyah. Agriculture occupies $85 \%$ of the national workforce of which $45 \%$ are women and livestock, on the other hand, accounts for only $13.3 \%$ of which $5 \%$ are women. This shows that women are involved more in agriculture than in livestock.

\subsection{Parcel and cultivated areas}

The areas cultivated by women represent $22 \%$ of total cultivated area at national level. In the region of Kindia it was observed that proportions of large areas cultivated by women in the prefectures is $48.7 \%$ in Télimélé, $26.5 \%$ in Kindia, $43.5 \%$ in Dubréka, 16, 5\% Forecariah and 10.14\% in Coyah (See Table 1).

Of the 189,345 cultivated area only 66825 are cultivated by women or $35.2 \%$. Télimélé has the largest number of area cultivated by women followed by Kindia and others, and smaller area cultivated by women was recorded in Coyah prefecture (See Table 2). Within the relief and water regimes, the rainfed crops are predominant and 
represent $97.65 \%$ of the total area against $1.8 \%$ in irrigated and $0.55 \%$ in recession areas (though recession acreage is relatively insignificant). Among the rainfed crops, $52 \%$ are located on hills or mountains and $38.6 \%$ on the plateau and $89.9 \%$ of the recession crops are located in mangrove. By the type of parcels, much of area cultivated by women is located on individual parcels.

\subsection{Participation in agricultural Works}

Among the tasks realised in parcels of exploitation, the participation of women is far less important in clearing and to a lesser extent ploughing. By cons, their share of contribution remains important in the seedling, maintenance of fields of crops and harvest (See Graph 3). On the parcel of exploitation and by area, the share of contribution of women to work is the highest observed of maintenance level, $60 \%$ of women participate in all maintenance. Women participate in more than $50 \%$ of harvesting and they account for nearly half the work of clearing. The low participation rate is observed at ploughing followed by seedling. In the areas owned by men, the participation of women is still higher at maintenance level and account for nearly $50 \%$ of harvesting.

\subsection{Diversification of activities}

Training on the subject determination and identification of objectives, prioritization and planning have led farmers to initiate other activities that help increase their assets (See Table 3).

Agriculture, livestock and trade of local products remain the primary activities of farmers. Women practise a relatively high activity than men. These diversifications of activities have enabled women to increase their assets and income thereby boosting the regional local economy.

\subsection{Livestock Production}

The livestock results presented the census of all animals available to farmers in the sample, extrapolated to all farm population of the administrative region of Kindia. In the region the number of livestock is approximately $1,044,202$. Women hold $48.2 \%$ of the regional livestock. In the prefectures, the religious barrier remains the main constraint on development of pig sector (See Graph 4). The share of livestock owned by women is important and varies depending on the species and animal categories from one prefecture to another. Overall, women hold $64 \%$ of poultry, $37 \%$ of goats, $33 \%$ of sheep and $43 \%$ of cattle. Women do not raise pigs and equines in the Kindia region.

Egg production is more intense in Kindia prefecture followed by Coyah prefecture, Dubréka and others. Télimélé has the largest milk production followed by Kindia. Women objective is to increase eggs and milk production, expansion of intensive poultry and improvement in personnel skills (See Table4).

\subsection{Farm Equipments}

Most of the farm equipments in the region of Kindia are composed of tillage equipments: hoes, spades, sickles, knives, axes, hoes, watering cans, plows and others as shown in the table below. The major equipment such as tractors and their accessories, harrows, planters, tillers, pumps ... are insignificant. The materials and equipment for farming and fishing are not as insignificant. The farm equipment which has the largest farms is livestock farms, while the materials and equipment are fishing nets and fish ponds. The rolling stock consists of bicycles. The rate of farm equipment is important for the small farm equipment. Regionally, the results show that no woman has tractor or harrow motorized or planter, cultivators, motor pump, store, storage, canoe and boat, let alone a tractor. Besides, the equipments most important for improving the productivity of traditional farms are also scares. (See Table 5)

The share of women is generally low because the percentage of equipment that belongs to them is quite low, even if they have more opportunities to use available equipments on the holding, it will still mean using men's equipments. Women have mostly minor tillage equipments such as machetes, sickles and watering cans.

\subsection{Constraints of women farmer in agricultural production in Kindia region}

From our findings, several constraints limit agricultural productivity in Kindia region:

a) Lack of funding to ensure the intensification of action in the development of infrastructure. The current level of funding is inadequate to meet the challenges of modern trends and needs;

b) Low awareness of the importance of production facilities by producers;

c) Lack of modern infrastructure and extension services to help create the needed awareness.

d) Low technical knowledge on the maintenance and repairs of machineries leading to inadequate care and management of community infrastructure by the beneficiaries of these facilities;

e) Insufficient capacity to further vocational training of operators; 
f) Lack of credit facilities tailored to the needs of operators of the projects;

g) Lack of facilities for the preservation and packaging of animal products (cold rooms, packaging materials, and cells);

h) Poor organization of marketing operators;

i) Failure to comply with the legislation on trading animals on hoof.

\section{Conclusion}

Women play a critical role to fight against poverty and food insecurity in the Kindia. Particularly in low income countries in which agriculture accounts for an average of $32 \%$ of the growth in GDP, and an average of $70 \%$ of the countries' poor people and work in rural areas where women farm activity is indispensable. In Kindia region the women farmer make up a substantial majority of the agricultural workforce and produce most of the food that is consumed locally. The women farmer activity is an engine of economic growth, and provides the basis for most rural livelihoods. The large proportion of agricultural production that is attributable to women farmer makes them important agents of economic development in the region. The vast majority of food production that is attributable to women farmer in Kindia region makes them the principal agents of poverty reduction and food security in rural areas (prefectures, districts). Despite the critical role they play in food production, they have ownership of only one percent of the land. Without secure tenure it is difficult for them to borrow small amounts of money to buy seeds and other essential inputs. They are often excluded from training and farmer's cooperatives. Lack of knowledge about their rights makes them vulnerable to land grabbing and disinheritance. As countless studies have now demonstrated, there are millions of poor rural women who produce at least half the food for mankind, and they are the pillar of developing rural economies. Without women the humanity would undoubtedly go hungry. They have the interest of their families most at heart and could undergo any subsistence activity to sustain their interest. Generally, women deserve more consideration and respect as we all live through their household efforts. Thus man grows and harvests, while women grow, harvests, processes, stack overwrites and prepare. So without women we can not talk about food security in Kindia and Africa as a whole. A woman without much agricultural assistance and nutrition, education does every activity to ensure her household remains healthy, and no one cares much about her own well-being. That is to say no freedom for a people who feed the hungry-the children and the most vulnerable.

\section{Recommendations}

The following recommendations are made to improve the lives of women farmer. Improving women's access to productive resources such as land, credit, and appropriate technologies to increase production and consumption of food crops; women literacy education programme is required to help women farmers acquire basic skills and abilities to seek and receive needed agricultural information through modern communication channels such as mass media and extension agents. The promotion and development of agricultural techniques adapted to women in terms of production, post-harvest agricultural activities and marketing. Government should encourage and assist women farmers by giving them special attention in terms of access to needed farm inputs. New farming equipment which will reduce drudgery and are affordable should be made available to women farmers. The situation of women farmer in Kindia region is a complex problem. Measures on improvement of their lot can not reach their target due to lack of knowledge of the various elements involved in the dynamics of the home. For policies and interventions intended to improve their situation to be effective, it is recommended to develop activities of research and collecting information on socio-cultural and financial conditions affecting rural women.

\section{References}

Addressing food security in Africa via multiple livelihood strategies of women farmers, [Online] Available: www.sciencedirect.com/science

Alpha Oumar KEBE. (2007). Forum de la Fédération des Organisations Paysannes de la Basse Guinée (FOP/BG) [Online] Available: www.certiferme.com/blog/article-14-146 perso-basse-guinée.

Camara, Moussa et al. (2010). Impact assessment of agriculture and livestock on food security in Guinea; Journal of agriculture, biotechnology and ecology, Vol.3 (3), p9-26.

Camara, Moussa et al. (2005). Etude d'impact des activités réalisées par l'ONG SARA au compte du Projet Pilote d'Appui au Programme Spécial pour la Sécurité Alimentaire de la FAO sur le développement économique et social des membres de l'union des producteurs de la CRD de Benty, Préfecture de Forecariah, 53 pages.

Erwin Northoff, ROME. (1998). (IPS) food: women farmers are invisible actors in hunger drama [Online] Available: www.ansa-africa.net/ uploads/ documents/ publication. 
FAO. (1996). Farmers rights in the conservation and use of plant genetic resources: A Gender Perspective. [Online] Available: www. aciar.gov.au/systeme/files/node/8925/women_farmers_knowledge.pdf

FAO. (1998). Women Feed the World - Tele Food Material, Rome

FAO. (2009). Etat de l'insécurité alimentaire dans le monde. [Online] Available: http://www.fao.org/docrep/012/i0876f00.htm

Keita, F.S. (2006). Balance at the sub-sector animal husbandry Guinea.

Loagun EU. (1998). Rural Women Training Needs: Preferences for Methods, Place, Duration and Time.

Obinne C. (1995). Rural Women in food chain Activities: A case of Ibospeaking Ethnic Community of Delta State, Nigeria. Agrores., vol.1 No 1, pp. 35-40.

Protz M. (1997). Developing Sustainable Agricultural Technologies with Rural Women in Jamaica: $A$ participatory media Approach. University of Reading, UK, pp. 1-3.

RNA/SNSA. (2000/2001). Recensement National de l'Agriculture-Service National des Statistiques Agricoles / Guinea report addressing for rural extension.

SNPRV Service national pour la promotion rurale et de la vulgarisation rurale Guinea Report addressing for Rural Extension December 2008.

The Hunger Project 5 Union Square West • New York, NY 10003 • www.thp.org/ Factsheet: Women Farmers and Food Security. [Online] Available: www.thp.org/system, files Factsheet.

Weisfeld-Adams and Emma. (2008). Women Farmers and Food Security. The Hunger Project 5 Union Square West $\bullet$ New York, NY 10003. [Online] Available: www.thp.org, Page 2 of 7.

WFS. (1996). World Food Summit, food security Para. 1. [Online] Available: www.Guinee44.com/index.php

Table 1. Distribution of areas cultivated by Prefecture (ha)

\begin{tabular}{|l|c|c|c|}
\hline Prefectures & Cultivated by men & Cultivated by women & Total \\
\hline Coyah & 7723 & 872 & 8596 \\
\hline Dubréka & 18279 & 14102 & 32381 \\
\hline Forécariah & 22007 & 4333 & 26339 \\
\hline Kindia & 39620 & 14317 & 53937 \\
\hline Télimélé & 34891 & 33201 & 68092 \\
\hline TOTAL & 122520 & 66825 & 189345 \\
\hline
\end{tabular}

Source (RNA/SNSA 2000/2001)

Table 2. Distribution of area cultivated by parcel and water regime

\begin{tabular}{|l|r|r|r|r|r|r|r|r|}
\hline \multirow{4}{*}{ Relief } & \multicolumn{5}{|c|}{ Cultivated by women } & \multicolumn{2}{c|}{ Total } \\
\cline { 2 - 6 } & \multicolumn{2}{|c|}{ Rainfed } & \multicolumn{2}{|c|}{ Irrigate } & \multicolumn{2}{|c|}{ Recession } & \multirow{2}{*}{ Area (ha) } & \\
\cline { 2 - 6 } & $\begin{array}{r}\text { Area } \\
\text { (ha) }\end{array}$ & $\%$ & $\begin{array}{r}\text { Area } \\
\text { (ha) }\end{array}$ & $\%$ & $\begin{array}{r}\text { Area } \\
\text { (ha) }\end{array}$ & $\%$ & & \\
\hline Mangrove & 418 & 0,6 & 37 & 3,1 & 337 & 89,9 & 792 & 1,2 \\
Shallow & 2873 & 4,4 & 168 & 14,0 & 38 & 10,1 & 3079 & 4,6 \\
Plain & 2785 & 4,3 & -- & -- & - & 0,0 & 2785 & 4,2 \\
Hill/ mountain & 33952 & 52,0 & 677 & 56,6 & -- & 0,0 & 34629 & 51,8 \\
Plateau & 25189 & 38,6 & 292 & 24,4 & -- & 0,0 & 25481 & 38,1 \\
Other & 38 & 0,1 & 21 & 1,7 & -- & 0,0 & 59 & 0,1 \\
Total relief & 65255 & 97,65 & 1195 & 1,8 & 375 & 0,55 & 66825 & 100,0 \\
\hline
\end{tabular}


Table 3. Situation of activities practiced by women

\begin{tabular}{|l|l|l|}
\hline Prefectures & Principal Activity & Secondary Activity \\
\hline Coyah & $\begin{array}{l}\text { Agriculture, } \\
\text { Livestock, Trade }\end{array}$ & $\begin{array}{l}\text { Extraction of salt, Market gardening, Trade, Soap making, technical } \\
\text { agri-food, Arts and crafts, Extraction of palm oil, Dried fish Other Activity }\end{array}$ \\
\hline Dubréka & $\begin{array}{l}\text { Agriculture, } \\
\text { Livestock, Trade }\end{array}$ & $\begin{array}{l}\text { Market gardening, Trade, Soap making, Technical agri-Food, Fishing, } \\
\text { delivery service, Other Activity, Dried fish, Arts and crafts }\end{array}$ \\
\hline Forécariah & $\begin{array}{l}\text { Agriculture, } \\
\text { Livestock, Trade }\end{array}$ & $\begin{array}{l}\text { Fishing, Market gardening, technical agri-food, Soap making, Forestry, } \\
\text { Trade, Arts and crafts, Extraction of palm and coconut oil, Dried fish, Other } \\
\text { Activity }\end{array}$ \\
\hline Kindia & $\begin{array}{l}\text { Agriculture, } \\
\text { Livestock, Trade }\end{array}$ & $\begin{array}{l}\text { Dye, delivery service, technical agri-food, Trade, Market gardening, } \\
\text { Floriculture, Forestry, Beekeeping Arts and crafts, Soap making, Other } \\
\text { Activity }\end{array}$ \\
\hline
\end{tabular}

Table 4. Monthly average production derived from livestock in Kindia region

\begin{tabular}{|l|c|c|c|c|}
\hline Products & total Production & Women production & Consume by family & Quantity Sold \\
\hline Eggs & 2302460 & 1646616 & 54976 & 1580582 \\
\hline Milk & 2915906 & 1538263 & 86109 & 1449960 \\
\hline
\end{tabular}

Table 5. Equipment of women farmer

\begin{tabular}{|l|r|r|r|}
\hline Equipments & $\begin{array}{r}\text { Total } \\
\text { Equipments }\end{array}$ & For Women & $\begin{array}{r}\text { Price by unit } \\
\text { USD/ \$ }\end{array}$ \\
\hline Hoe/ Spade & 675176 & 179425 & 1.59 \\
\hline Machete / Coupe-coupe & 451268 & 60995 & 1.17 \\
\hline Ax & 142898 & 42483 & 0.63 \\
\hline Sickles / Knife & 474922 & 169710 & 0.79 \\
\hline Pickaxe & 15601 & 1571 & 1 \\
\hline Secateurs & 907 & 338 & 0.56 \\
\hline Rake & 14195 & 1738 & 0.82 \\
\hline watering & 9329 & 1182 & 1.4 \\
\hline Harrow hitched & 65 & 22 & 7,3 \\
\hline Sheller & 50 & 15 & 436.8 \\
\hline Drying area Products & 5439 & 1071 & 1.35 \\
\hline Store room for agricultural Products & 56 & 20 & 78 \\
\hline Livestock Park & 21984 & 18762 & 3.11 \\
\hline Barn and Equipments & 706 & 267 & 3.36 \\
\hline Nasse & 2450 & 1063 & 22.45 \\
\hline Wheelborrow & 3279 & 1051 & 4.6 \\
\hline Shotgun & 17375 & 605 & 17.61 \\
\hline Spray & 40 & 25 & 4.68 \\
\hline Plow & 1343 & 0 & 14.70 \\
\hline Beef & 355 & 45 & 117 \\
\hline Bicycle & 2078 & 129 & 18.5 \\
\hline
\end{tabular}




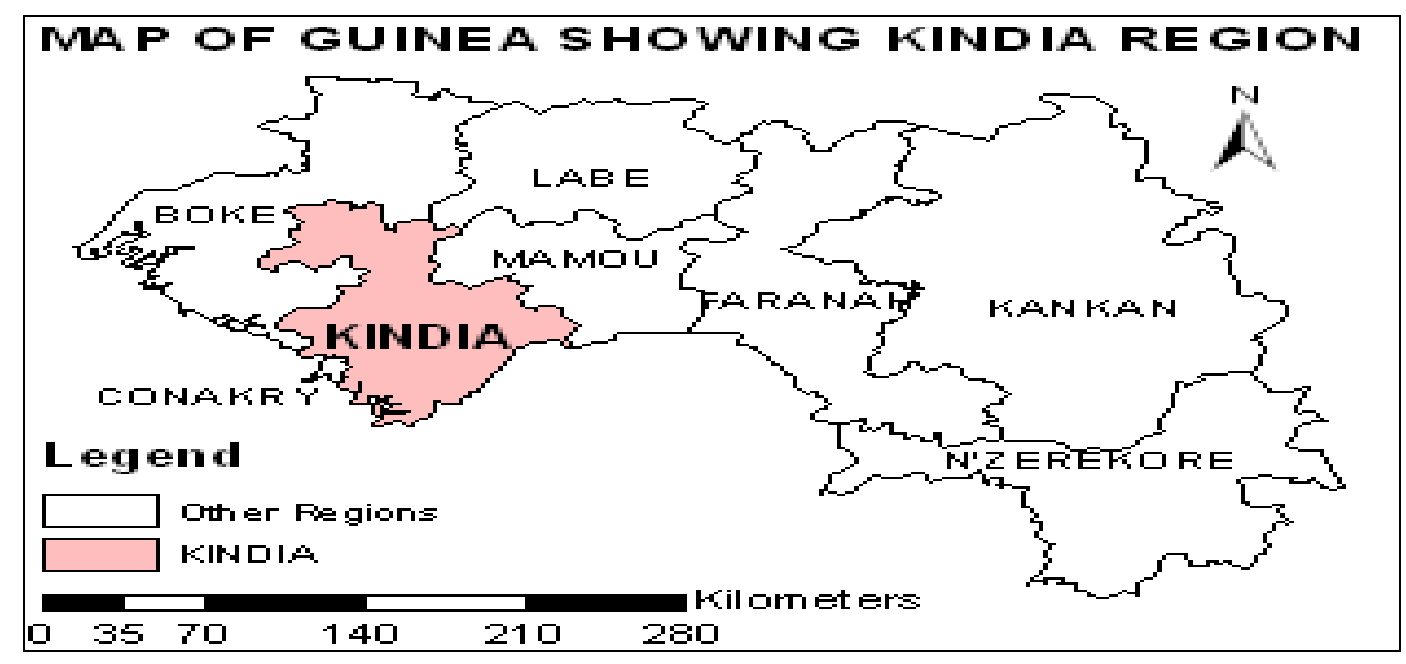

Map of Guinea showing Kindia Region

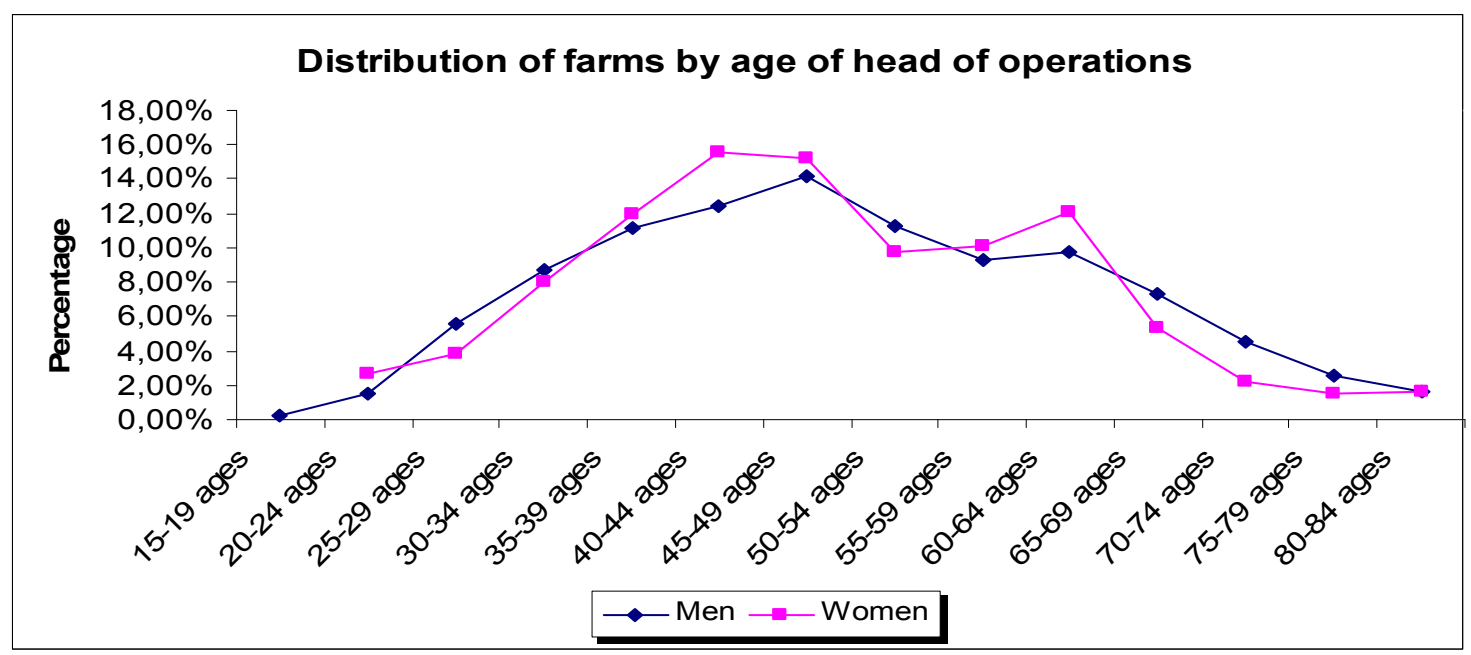

Graph 1. Distribution of farms by age of head of operations

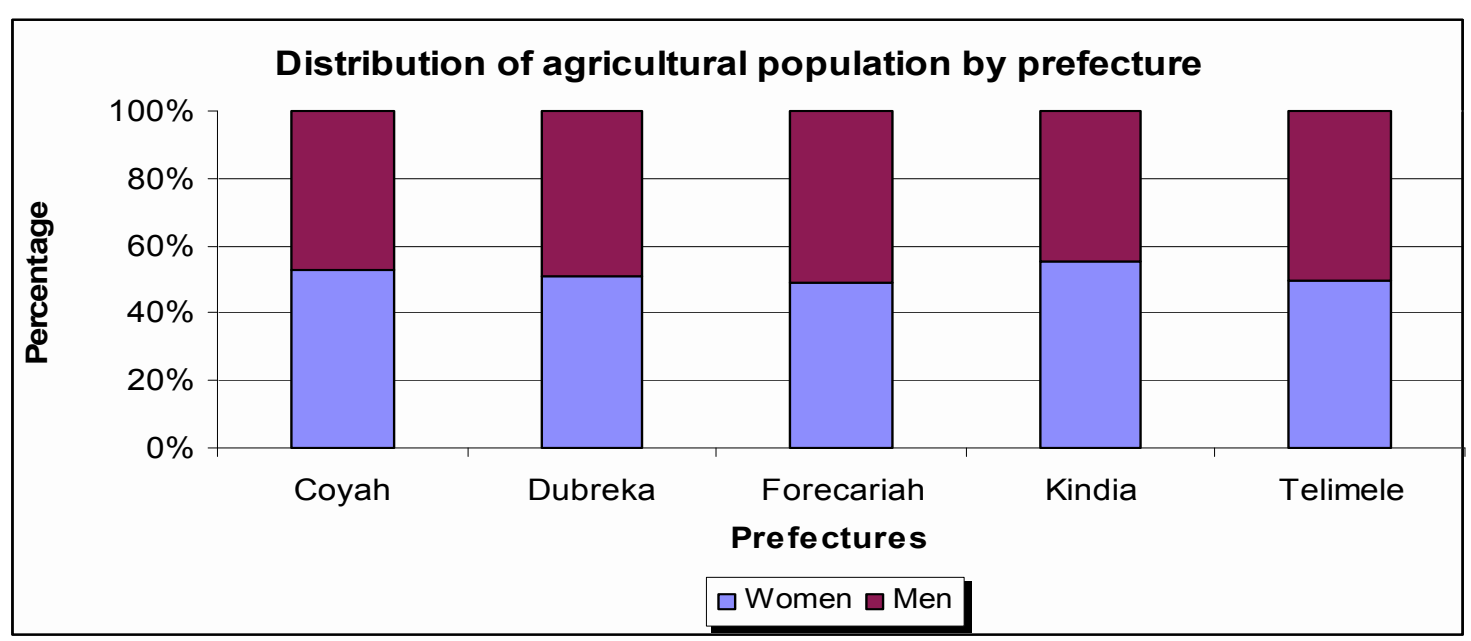

Graph 2. Distribution of agricultural population 


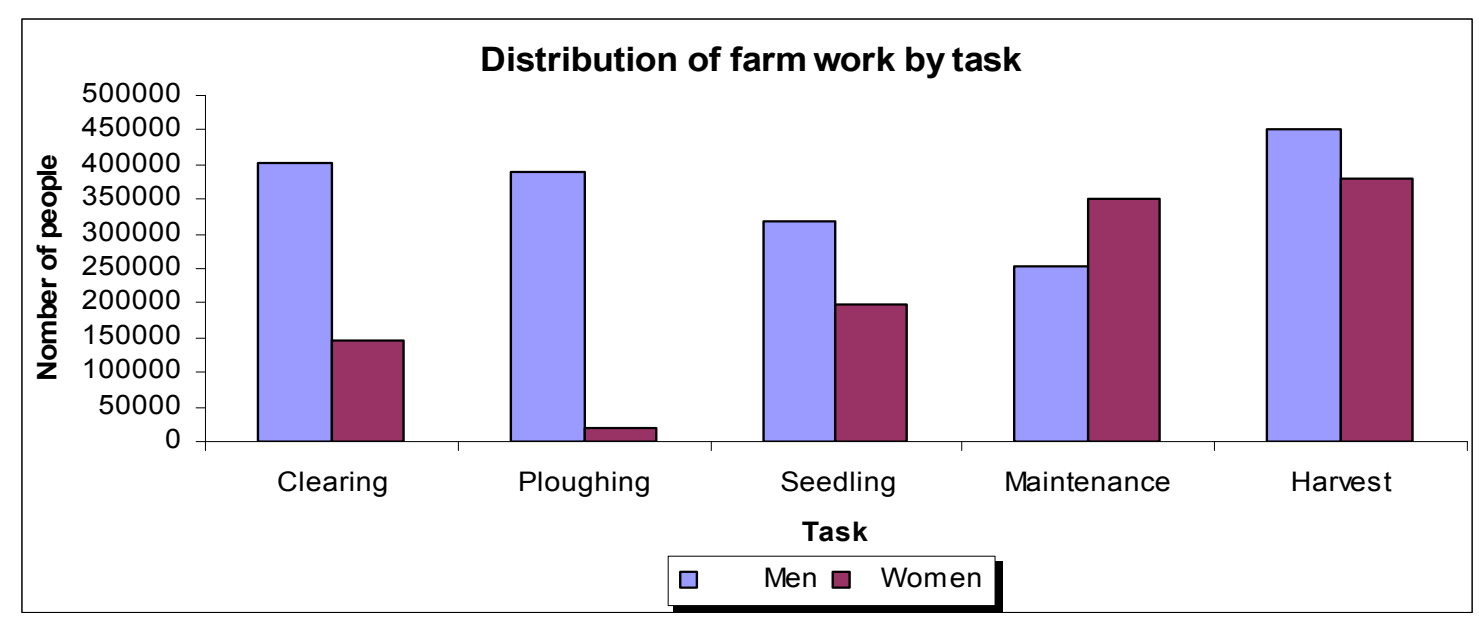

Graph 3. Distribution of farm works by task

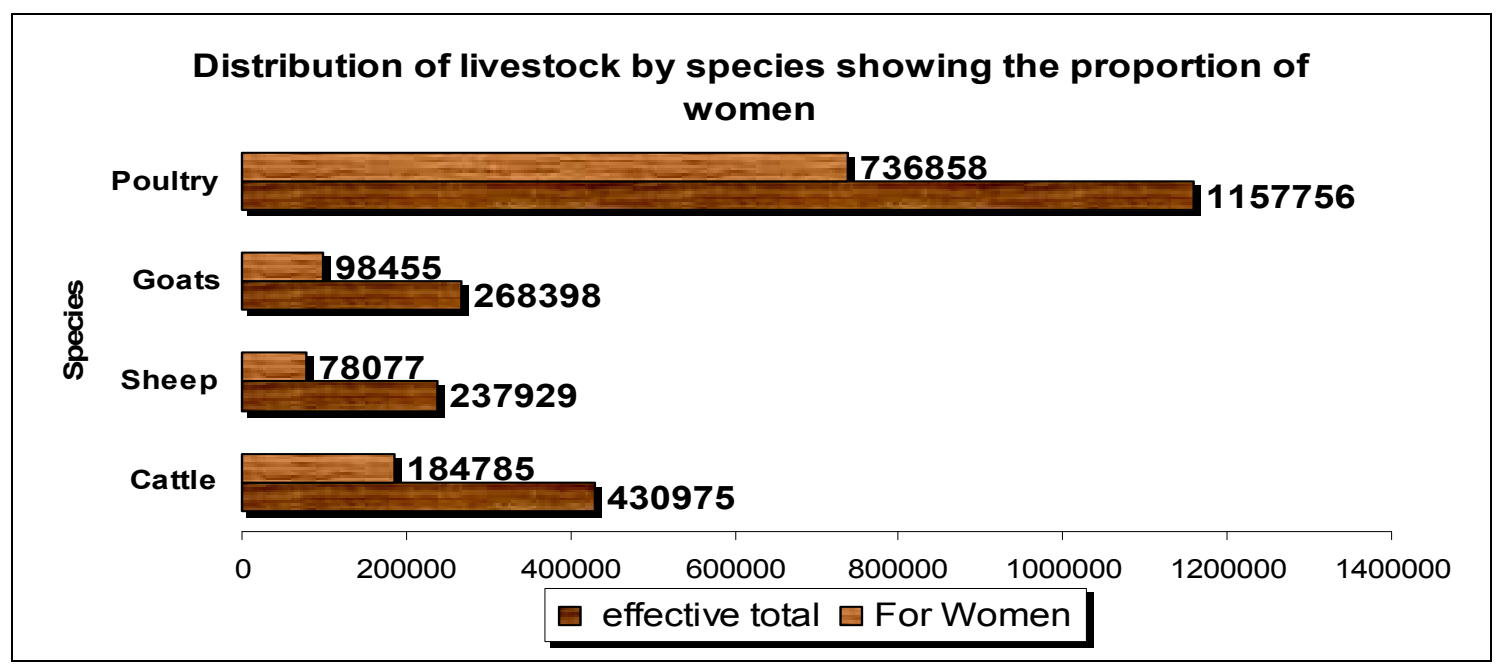

Graph 4. Distribution of livestock by species 